\title{
Phenology and thermal indices of maize (Zea mays L.) influenced by subsoil compaction and nitrogen fertilization under semi-arid irrigated conditions
}

\author{
Jagdish Singh* and M. S. Hadda \\ Department of Soil Science, Punjab Agricultural University, Ludhiana-141004 (Punjab), INDIA \\ *Corresponding author. E-mail: jagdishsingh@ pau.edu
}

Received: June 03, 2014: Revised received: August 05, 2014 ; Accepted: September 17, 2014

\begin{abstract}
The magnitude of yield reduction due to soil compaction is variable and depends on the soil type, fertility status and other soil and environmental factors. The present investigation was carried out at the research farm, Department of Soil Science, Punjab Agricultural University, Ludhiana. The experiment was conducted to evaluate the effect of different levels of subsoil compaction and nitrogen fertilization on maize phenology, yield and heat use efficiency. The $C_{2}$ (subsoil bulk density $\left(D_{b}\right)=>1.8 \mathrm{Mg} \mathrm{m}^{-3}$ ) treatment reduced yield by 15.5 and $24.3 \%$ and heat use efficiency (HUE) by 15.2 and $20.9 \%$ than that in $C_{0}$ (subsoil $D_{b}=1.55-1.65 \mathrm{Mg}$ $\mathrm{m}^{-3}$ ) treatment during the year 2012 and 2013, respectively. The tasseling and silking stage was delayed, while physiological maturity was advanced under $\mathrm{C}_{2}$ subsoil compaction treatment than that in $\mathrm{C}_{0}$ treatment. The $\mathrm{N}_{2}$ treatment improved the yield by 14.9 and $13.9 \%$ and HUE by 15.2 and $14.3 \%$ than that in $\mathrm{N}_{0}$ treatment during the year 2012 and 2013, respectively. Maize took more days to reach physiological maturity under $\mathrm{N}_{2}$ treatment as compared to $\mathrm{N}_{0}$ treatment. Phenothermal index (PTI) showed that crop reached different stages earlier under $\mathrm{C}_{1}$ and $\mathrm{C}_{2}$ than that of $\mathrm{C}_{0}$. The data emphasized the need to take care of soil strength and soil temperature related parameters along with weather conditions for better yield prediction using thermal time.
\end{abstract}

Keywords: Accumulated growing degree days (AGDD), Heat use efficiency (HUE), Nitrogen levels, Phenology, Phenothermal index (PTI), Subsoil compaction

\section{INTRODUCTION}

The continuous use of heavy equipment for agricultural cultivation (ploughing/puddling, leveling, sowing, harvesting, etc.) throughout the world has resulted in increased soil compaction on agricultural land affecting crop production (Abu-Hamdeh, 2003). Flowers and Lal (1998) reported that the depth of compaction varies from 10 to $60 \mathrm{~cm}$ due to vehicular traffic over the field, but the ill effects on crop growth are more pronounced when compact layer formed just below the plough layer. An increase in soil bulk density (Sur et al., 1980) and decrease in total porosity and the proportion of larger pores to smaller pores (Motavalli et al., 2003) are some of the detrimental effects of soil compaction. These changes in physical properties of soils lead to reduced plant growth and production mainly by restricting root growth, decreased soil water and nutrient availability and lower soil aeration (Domzal et al., 1991). The restrictive effect of soil compaction can be physical and physiological, affecting plant growth and yield (Iijima et al., 1991).

Nitrogen $(\mathrm{N})$ fertilization plays a significant role in improving soil fertility (Habtegebrial et al., 2007), and results in increased vegetative growth and ISSN : 0974-9411 (Print), 2231-5209 (Online) All Rights Reserved ๑ Applied and Natural Science Foundation www.ansfoundation.org biomass of maize (Ogola et al., 2002). Nitrogen is most yield limiting nutrient, its stress reduces grain yield by delaying plant growth and development. Maize is usually considered to have a high soil fertility requirement to achieve maximum yield (Uribelarrea et al., 2009). Thus, it require large quantities of $\mathrm{N}$ for optimal growth and yield. Shafi et al. (2007) also reported increased maize yield with the application of $\mathrm{N}$ fertilizer. Maize starts to take up $\mathrm{N}$ rapidly at the middle of vegetative growth period and maximum $\mathrm{N}$ uptake occur near silking stage (Hanway, 1963). N deficiencies at such stages reduce maize growth and consequently, biomass yield (Uhart and Andrade, 1995). To overcome the ill effects of compaction farmers over fertilize the crop with high analysis fertilizer such as Urea.

Characterizing and understanding crop phenology is vital for crop management practices such as fertilization and irrigation scheduling (Streck et al., 2008). It is useful to assess if the most critical stages of growth occur during periods of favorable weather and soil fertility conditions. Air temperature based agrometeorological indices viz., growing degree days (GDD) and phenothermal index (PTI) have been used to describe changes in phenological behaviour and growth parameters (Streck et al., 
2008; Kumar et al., 2010). Crop phenology is primarily affected by the air temperature and secondarily by the soil temperature. Some studies (Stone et al., 1999) reported that maize development is controlled by the temperature of the meristem, which lies underground. It was assumed to be affected by soil bulk density and soil temperature which are altered by soil compaction. A little information is available on the consequences of compact subsurface layer on the crop growth and development. Thus, the present study was initiated with the objective to access the effect of subsoil compaction and nitrogen fertilization on the phenology, yield and heat use efficiency of maize.

\section{MATERIALS AND METHODS}

Site description, experimental design and treatments: The present experiment was conducted at research farm of Department of Soil Science, Punjab Agricultural University, Ludhiana during the summer season of 2012 and 2013. The site is situated at $30^{\circ} 54^{\prime} \mathrm{N}$ latitude and $75^{\circ} 48^{\prime} \mathrm{E}$ longitude with an altitude of 247 metres above the mean sea level, in the central plain region of Punjab under Trans-Gangetic agro-climatic zone of India. It represents sub-tropical and semi-arid climate with very hot and dry summer from April to June, hot and humid conditions from July to September, cold winters from November to January and mild climate during February and March. About $75 \%$ of the average annual rainfall is received during July to September months. The soil was classified as alluvial, sandy loam in texture, calcareous and Typic Haplustept. The physico-chemical properties of soil are given in Table 1.

The treatments were arranged in a split-plot design with three blocks. Three subsoil compaction levels were kept in main plot treatments while three doses of $\mathrm{N}$ were kept under subplot treatment. The subsoil compaction treatments were given by removing the surface $15-\mathrm{cm}$ soil and then compacting the sub-surface layer with passes of tractor mounted roller to achieve the desired bulk density. After achieving desired bulk density, surface soil was put back on the place. The subsoil compaction treatments were $\mathrm{C}_{0^{-}}$Control (bulk density, $\mathrm{Db}=1.55-1.65 \mathrm{Mg} \mathrm{m}^{-3}$ ), $\mathrm{C}_{1}$ - Moderate compaction, $\left(\mathrm{Db}=1.70-1.75 \mathrm{Mg} \mathrm{m}^{-3}\right.$ ) and $\mathrm{C}_{2}$ - High compaction ( $\mathrm{Db}>1.80 \mathrm{Mg} \mathrm{m}^{-3}$ ) at 15-30 cm depth. The nitrogen treatments were $\mathrm{N}_{0}-155 \mathrm{Kg} \mathrm{N} \mathrm{ha}^{-1}, \mathrm{~N}_{1}-195 \mathrm{Kg} \mathrm{N} \mathrm{ha}^{-1}$ and $\mathrm{N}_{2}-235 \mathrm{Kg} \mathrm{N}$ ha $^{-1}$.

Cultural practices: The maize was sown on June 27 during 2012 and June 22 during 2013. Sowing was done on the same day for all plots with row to row spacing of $60 \mathrm{~cm}$ and plant to plant spacing of $20 \mathrm{~cm}$, during each year of the study. Phosphorus, potassium and zinc sulphate were applied @ 60, 30 and $25 \mathrm{~kg} \mathrm{ha}^{-1}$, respectively. Entire quantity of P, K and zinc sulphate with one third of $\mathrm{N}$ (as Urea $46 \%$ $\mathrm{N})$ was applied at sowing and remaining $\mathrm{N}$ was applied in two equal splits i.e. at knee high and at pre-tasselling stages. Irrigation was applied at regular intervals as per the crop demand to avoid water stress at any stage. Recommended cultural practices were employed to ensure proper weed, insect and pest control (Anonymous, 2012).

Crop and weather measurements: The time of emergence was considered as the date when the coleoptiles of $50 \%$ of planted seeds were emerged from above the soil surface. Days taken to tasselling and silking were recorded as the number of days taken from planting to the date when the tassels and silks were emerged on 50 per cent of plants in the plot. The dough stage was recorded when 50 per cent of plants in the plot had whitish yellow to yellow kernels and fingernail impression was retained on them. Number of days taken to physiological maturity was recorded from the date of planting to the date when 50 per cent plants showed browning or drying of ear husk.

Growing degree days (GDD) as a measure of thermal time, were calculated by simple arithmetic accumulation of daily mean temperature above the base temperature value of $10^{\circ} \mathrm{C}$ considered for the maize crop. The growing degree days for each stage Growing degree days ( ${ }^{\circ} \mathrm{C}$ days $)=\sum_{i=1}^{n} \mathrm{~T}_{i}-\mathrm{T}_{\mathrm{b}}$ were calculated as (Nuttonson, 1955):

(1)

Where, $\mathrm{i}$ is the $\mathrm{ith}$ day from sowing, Ti is mean temperature for that day, $\mathrm{n}$ is the number of days in the growing season (Ellis et al., 1990) and Tb is Base temperature and was taken equal to $10^{\circ} \mathrm{C}$. The heat use efficiency was calculated using the following formula:

Heat use efficiency $\left(\mathrm{Kg} / \mathrm{ha} /{ }^{\circ} \mathrm{C}\right.$ days $=$ Grain matter yield $(\mathrm{Kg} / \mathrm{Ha}) / \mathrm{AGDD}\left({ }^{\circ} \mathrm{C}\right.$ days $)$

AGDD is accumulated growing degree days ( $\mathrm{C}$ day) is sum of GDD acquired by crop during life cycle. Pheno thermal index (PTI) is the ability of the plant to utilize thermal heat for its development. PTI was calculated as:

Phenothermal Index $\left({ }^{\circ} \mathrm{C}\right.$ days $\left.^{-1}\right)=$ GDD / Number of day taken between two phenophases

All the ears from each net harvested plot were sun dried for three days and shelled. Moisture content of grains from each plot was determined. The grain yield was adjusted to $15 \%$ moisture level and expressed in $\mathrm{t} \mathrm{ha}^{-1}$. Rainfall, evaporation, daily maximum and minimum temperatures (Figs. 1, 2) were recorded at Agrometeorological Observatory, Punjab Agricultural University, Ludhiana for the period of $21^{\text {th }}$ of June to $28^{\text {th }}$ of October of the year 2012 and 2013. 
Statistical analysis: Statistical analysis was done as per the standard procedure given by Gomez and Gomez (1984) for the analysis of variance for split plot design. Mean separations using least significant difference (LSD) were determined for treatment effects when F-tests were significant at $\mathrm{P}$ values $<0.05$.

\section{RESULTS AND DISCUSSION}

Effect of subsoil compaction and nitrogen fertilization on phenology of maize: The perusal of data (Table 2) shows that the higher level of subsoil compaction $\left(\mathrm{C}_{2}\right)$ significantly advanced the days taken to emergence during the year 2013. Maize crop took almost 10 days to complete germination in plot with no subsoil compaction, while germination advances by about 3 days with increased level of subsoil compaction over no subsoil compaction treatment during the year 2013. Higher soil moisture at the time of sowing during the year 2013, might be responsible for advancement of emergence during year 2013, because rainfall occurred few days prior to the sowing of crop.

The crop took 48-52 days during the year 2012 and 55-60 days during 2013 to appearance of tassel (Table 2). The subsoil compaction delays the $50 \%$ tasseling by 4 days during 2012 and about 5 days during 2013. It had delayed the $50 \%$ silking by about 4 days during 2012 and 2013 than that in no subsoil compaction treatment. The delaying of $\mathrm{t}$ asseling and silking may be attributed to the higher level of subsoil compaction which restricted the

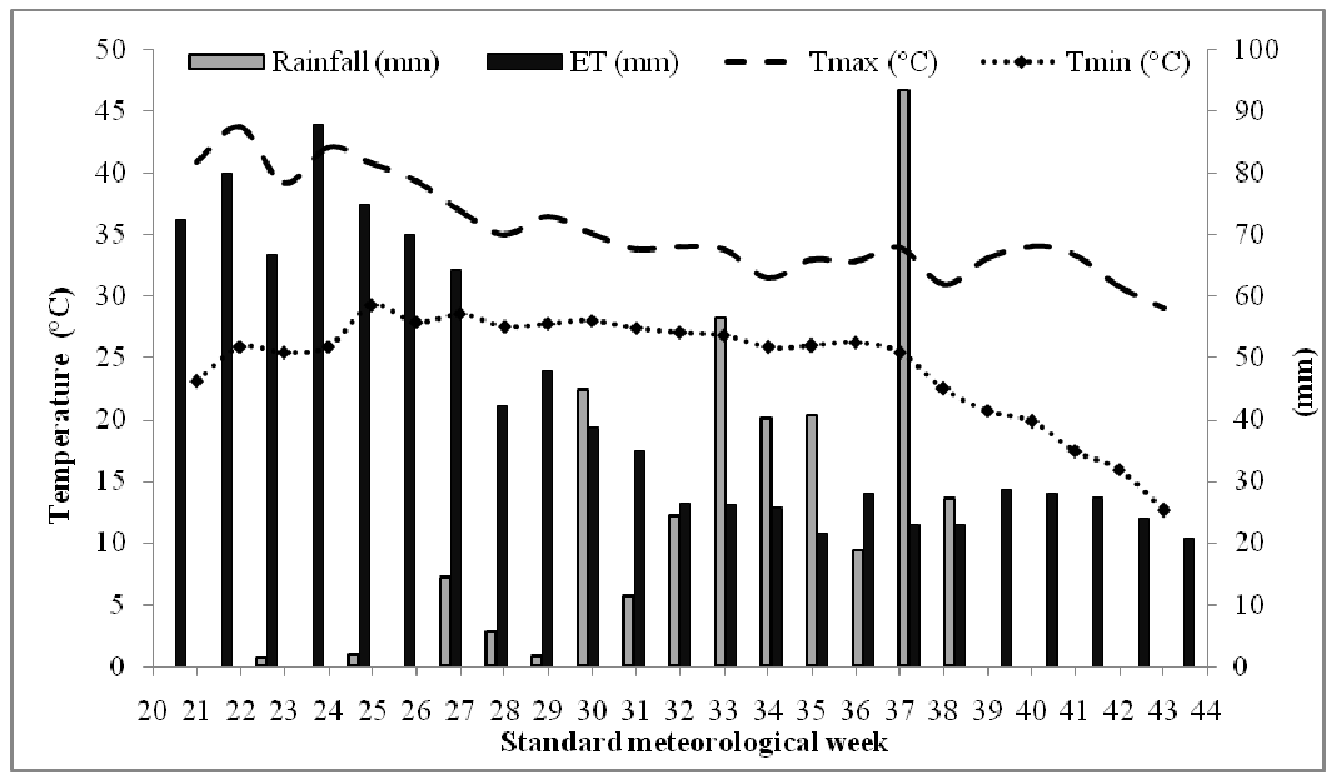

Fig.1. Weather observations from $21^{\text {th }}$ of June to $28^{\text {th }}$ of October of the year 2012.

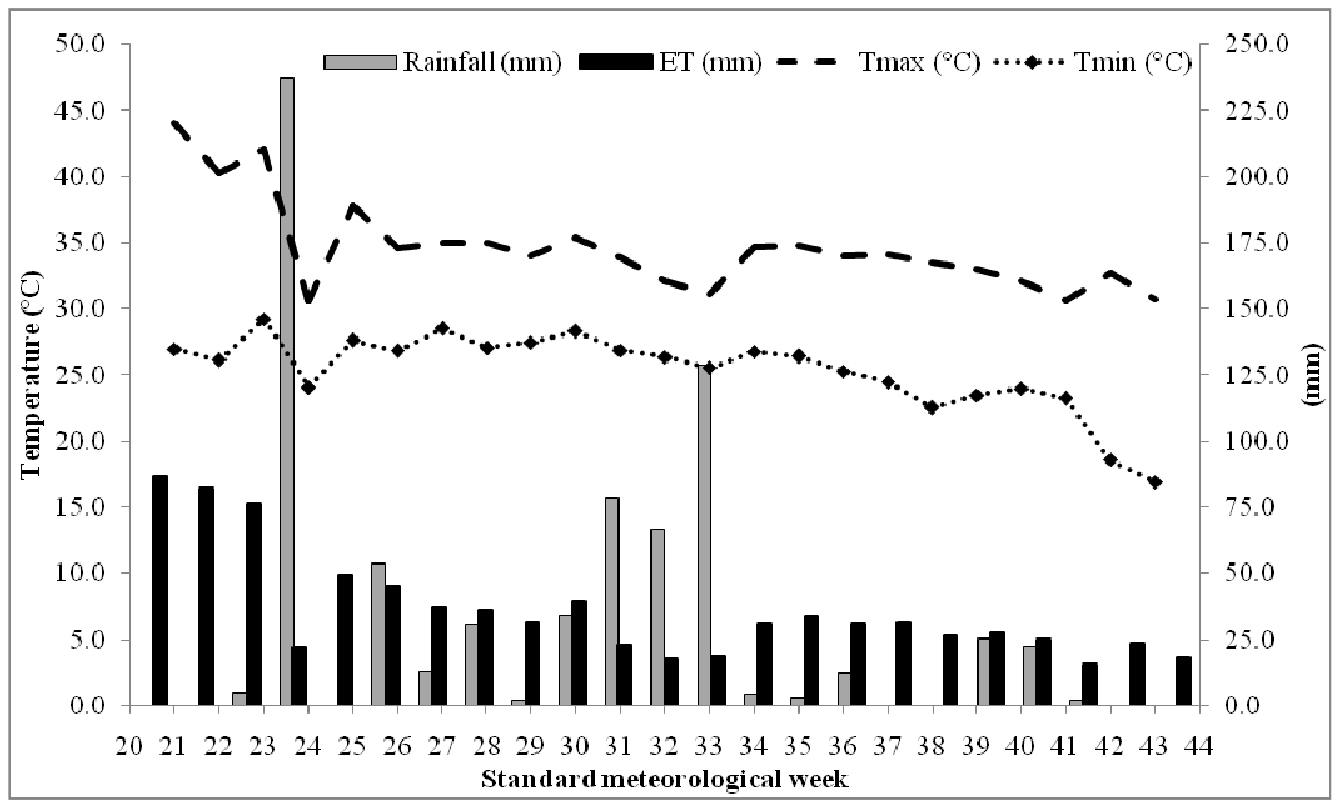

Fig. 2. Weather observations from $21^{\text {th }}$ of June to $28^{\text {th }}$ of October of the year 2013. 
Table 1. Soil physico-chemical properties of experimental site.

\begin{tabular}{|c|c|}
\hline Parameter & Value \\
\hline Sand (\%) & 64.8 \\
\hline Silt $(\%)$ & 17.9 \\
\hline Clay $(\%)$ & 16.3 \\
\hline Bulk density, $\left(\mathrm{Mg} \mathrm{m}^{-3}\right)$ & \\
\hline $0-15 \mathrm{~cm}$ depth & 1.49 \\
\hline $15-30 \mathrm{~cm}$ depth & 1.67 \\
\hline $\mathrm{pH}$ & 7.63 \\
\hline $\mathrm{E} \mathrm{C}\left(\mathrm{dS} \mathrm{m} \mathrm{m}^{-1}\right)$ & 0.51 \\
\hline $\begin{array}{l}\text { Plant available water }(\mathrm{cm} / 180 \\
\mathrm{cm} \text { profile })\end{array}$ & 21.8 \\
\hline $\begin{array}{l}\text { Saturated hydraulic conduc- } \\
\text { tivity }(\mathrm{cm} \mathrm{hr}-1) \\
0-15 \mathrm{~cm} \text { depth } \\
15-30 \mathrm{~cm} \text { depth }\end{array}$ & $\begin{array}{l}5.87 \\
1.95\end{array}$ \\
\hline
\end{tabular}

phenological parameters of maize were significantly affected by the amount of $\mathrm{N}$ fertilization and deep tillage.

The subsoil compaction advanced the dough stage by about 6 days and 4 days during the year 2012 and 2013, respectively (Table 2), than that in no subsoil compaction treatment. $\mathrm{N}$ application delayed dough stage by about 4 days and 3 days during the year 2012 and 2013, respectively. The delay in the dough stage with higher dose of $\mathrm{N}$ fertilizer is attributed to the higher vegetative growth under higher level of $\mathrm{N}$ application over the lower $\mathrm{N}$ application.

The subsoil compaction advanced the physiological maturity by about 7 days and 6 days (Table 2) during the year 2012 and 2013, respectively over no subsoil compaction treatment. The advancement in physiological maturity under higher level of subsoil compaction is attributed to lesser plant growth resulting from restricted root growth and shortened

Table 2. Effect of subsoil compaction and nitrogen fertilization on phenology of maize during 2012 and 2013.

\begin{tabular}{|c|c|c|c|c|c|c|c|c|c|c|}
\hline \multirow{2}{*}{ Treatments } & \multicolumn{2}{|c|}{ Emergence } & \multicolumn{2}{|c|}{$50 \%$ Tasseing } & \multicolumn{2}{|c|}{$50 \%$ Silking } & \multicolumn{2}{|c|}{ Dough stage } & \multicolumn{2}{|c|}{$\begin{array}{c}\text { Physiological } \\
\text { maturity }\end{array}$} \\
\hline & 2012 & 2013 & 2012 & 2013 & 2012 & 2013 & 2012 & 2013 & 2012 & 2013 \\
\hline \multicolumn{11}{|c|}{ Subsoil compaction levels } \\
\hline $\mathrm{C} 0$ & 7.4 & 10.1 & 48.8 & 55.4 & 54.8 & 60 & 81.3 & 75.9 & 97.2 & 91.67 \\
\hline $\mathrm{C} 1$ & 7.2 & 7.2 & 51.4 & 57.7 & 56.6 & 63.5 & 77.6 & 74.3 & 94.4 & 89.0 \\
\hline $\mathrm{C} 2$ & 7.0 & 7.0 & 52.8 & 60.4 & 59.1 & 64.6 & 74.7 & 71.3 & 90.8 & 85.0 \\
\hline LSD- C & $\mathrm{ns}$ & 1.5 & 3.01 & 3.49 & 2.9 & 3.61 & 4.29 & 3.46 & 2.77 & 4.87 \\
\hline \multicolumn{11}{|c|}{ Nitrogen levels } \\
\hline N0 & 7.1 & 8.0 & 52.3 & 59.4 & 58.2 & 64.3 & 76.0 & 72.1 & 92.3 & 86.6 \\
\hline N1 & 7.3 & 8.0 & 51.1 & 57.5 & 56.8 & 62.6 & 78.0 & 73.8 & 94.2 & 88.0 \\
\hline $\mathrm{N} 2$ & 7.2 & 8.3 & 49.6 & 56.6 & 55.4 & 61.2 & 79.7 & 75.8 & 95.9 & 91.0 \\
\hline LSD- N & ns & ns & 1.32 & 2.01 & 1.16 & 2.14 & 2.16 & 2.73 & 1.59 & 2.52 \\
\hline $\begin{array}{l}\text { LSD C } \times N \\
(\mathrm{P}=0.05)\end{array}$ & ns & ns & ns & ns & ns & ns & ns & ns & ns & ns \\
\hline
\end{tabular}

growth and expansion of roots, thus adversely affecting the plant growth and development. Nitrogen being the most limiting nutrient to crop production significantly delayed the days to $50 \%$ tasseling and silking stage. An increase in the dose of $\mathrm{N}$ from 155 $\mathrm{kg} \mathrm{N} \mathrm{ha}^{-1}$ to $235.0 \mathrm{~kg} \mathrm{~N} \mathrm{ha}^{-1}$ significantly advanced the tasseling and silking during both the years. The increasing in $\mathrm{N}$ dose resulted in advancement in the occurrence of tasseling by 3 days during 2012 and about 4 days during 2013 than that in no subsoil compaction treatment. An increasing in $\mathrm{N}$ dose had advanced in the occurrence of silking by about 3 days during 2012 and 2013. Our results confirms the findings of Dawadi and Sah (2012) who reported that increasing $\mathrm{N}$ level decreased the number of days to reach tasseling and silking. Abayomi and Adedoyin (2004) also found that application of higher dose of $\mathrm{N}$ significantly reduces time to tassels and silk emergence. Gajri et al. (1994) also reported that period of flowering and grain filling. $\mathrm{N}$ application delays physiological maturity by 3 days during 2012 and 5 days during 2013. The delay in the physiological maturity with higher dose of $\mathrm{N}$ application is attributed to the higher vegetative growth as compared to lower $\mathrm{N}$ dose. Ali et al. (2012) found that increasing dose of $\mathrm{N}$ application in maize delays physiological maturity, because higher $\mathrm{N}$ level delays leaf senescence, sustain photosynthesis longer, extend duration of vegetative growth and increase succulence of plants.

Effect of subsoil compaction and $\mathbf{N}$ fertilization on thermal requirement for various phenophases: The concept of thermal time or Growing degree days (GDD) have been extensively used to illustrate and elucidate the effect of temperature on emergence and establishment of crops. The subsoil compaction and nitrogen levels (emergence, tasseling, silking, dough stage and maturity) had shown an increasing 
Table 3. Growing degree days $\left({ }^{\circ} \mathrm{C}\right.$ days) taken by the maize crop under different levels of subsoil compaction and nitrogen fertilization.

\begin{tabular}{|c|c|c|c|c|c|c|c|c|c|c|}
\hline \multirow[t]{2}{*}{ Treatments } & \multicolumn{2}{|c|}{ Emergance } & \multicolumn{2}{|c|}{ 50\% Tasseling } & \multicolumn{2}{|c|}{ 50\% Silking } & \multicolumn{2}{|c|}{ Dough stage } & \multicolumn{2}{|c|}{$\begin{array}{c}\text { Physiological } \\
\text { maturity }\end{array}$} \\
\hline & 2012 & 2013 & 2012 & 2013 & 2012 & 2013 & 2012 & 2013 & 2012 & 2013 \\
\hline \multicolumn{11}{|c|}{ Subsoil compaction levels } \\
\hline $\mathrm{C} 0$ & 195.8 & 245.8 & 1067.6 & 1182.1 & 1181.6 & 1268.7 & 1688.4 & 1596.7 & 1956.9 & 1894.1 \\
\hline $\mathrm{C} 1$ & 191.7 & 186.4 & 1119.2 & 1223.4 & 1216.0 & 1339.2 & 1627.2 & 1564.5 & 1909.5 & 1844 \\
\hline $\mathrm{C} 2$ & 187.6 & 182.0 & 1143.2 & 1276.8 & 1261.0 & 1362.7 & 1573.3 & 1501.8 & 1847.7 & 1774.5 \\
\hline Mean & 191.7 & 204.7 & 1110.0 & 1227.4 & 1219.5 & 1323.5 & 1629.6 & 1554.3 & 1904.7 & 1837.5 \\
\hline \multicolumn{11}{|c|}{ Nitrogen levels } \\
\hline N0 & 189.6 & 204.3 & 1134.5 & 1256.1 & 1245.3 & 1356.2 & 1598.6 & 1518.6 & 1873.0 & 1804.0 \\
\hline N1 & 193.7 & 204.3 & 1114.1 & 1219.6 & 1219.7 & 1320.4 & 1634.6 & 1554.2 & 1906.0 & 1826.8 \\
\hline $\mathrm{N} 2$ & 191.7 & 209.8 & 1084.3 & 1203.6 & 1193.3 & 1292.8 & 1661.6 & 1594.7 & 1935.2 & 1881.3 \\
\hline Mean & 191.6 & 206.1 & 1110.9 & 1226.4 & 1219.4 & 1323.1 & 1631.6 & 1555.8 & 1904.7 & 1837.3 \\
\hline
\end{tabular}

Table 4. Phenothermal Index (PTI) taken by the maize crop under different levels of subsoil compaction and nitrogen fertilization.

\begin{tabular}{|c|c|c|c|c|c|c|c|c|c|c|}
\hline \multirow[t]{2}{*}{ Treatments } & \multicolumn{2}{|c|}{ Emergence } & \multicolumn{2}{|c|}{$50 \%$ Tasseling } & \multicolumn{2}{|c|}{$50 \%$ Silking } & \multicolumn{2}{|c|}{ Dough stage } & \multicolumn{2}{|c|}{$\begin{array}{c}\text { Physiological } \\
\text { maturity }\end{array}$} \\
\hline & 2012 & 2013 & 2012 & 2013 & 2012 & 2013 & 2012 & 2013 & 2012 & 2013 \\
\hline \multicolumn{11}{|c|}{ Subsoil compaction levels } \\
\hline $\mathrm{CO}$ & 26.46 & 24.34 & 20.58 & 20.36 & 19.00 & 18.83 & 19.12 & 20.63 & 16.89 & 18.86 \\
\hline $\mathrm{C} 1$ & 26.63 & 25.89 & 20.29 & 20.07 & 18.62 & 19.97 & 19.58 & 20.86 & 16.80 & 19.01 \\
\hline $\mathrm{C} 2$ & 26.80 & 26.00 & 20.04 & 20.00 & 18.70 & 20.45 & 20.02 & 20.76 & 17.04 & 19.91 \\
\hline Mean & 26.63 & 25.41 & 20.31 & 20.14 & 18.77 & 19.75 & 19.57 & 20.75 & 16.91 & 19.26 \\
\hline \multicolumn{11}{|c|}{ Nitrogen levels } \\
\hline No & 26.70 & 25.54 & 20.14 & 20.01 & 18.78 & 20.43 & 19.85 & 20.82 & 16.83 & 19.68 \\
\hline N1 & 26.53 & 25.54 & 20.35 & 20.10 & 18.53 & 19.76 & 19.57 & 20.88 & 16.75 & 19.20 \\
\hline $\mathrm{N} 2$ & 26.63 & 25.28 & 20.50 & 20.17 & 18.79 & 19.39 & 19.27 & 20.68 & 16.89 & 18.86 \\
\hline Mean & 26.62 & 25.45 & 20.33 & 20.09 & 18.70 & 19.86 & 19.56 & 20.79 & 16.83 & 19.25 \\
\hline
\end{tabular}

trend of heat unit (GDD) (Table 3). Among the subsoil compaction treatments, the $\mathrm{C}_{0}$ treatment registered higher GDD to attain physiological maturity over $\mathrm{C}_{1}$ and $\mathrm{C}_{2}$ treatment. The AGDD ranged from 1847.7 to $1956.9{ }^{\circ} \mathrm{C}$ days in the year 2012 , and 1774.5 to $1894.1{ }^{\circ} \mathrm{C}$ days in 2013 under different subsoil compaction levels. The reduction in GDDs consumed by the maize to attain various phenophases under higher levels of subsoil compaction might be attributed to reduced growing period and poor rooting depth of maize. Thus it affected the uptake of growth resources specially, nutrient and water.

Among the nitrogen treatments, the $\mathrm{N}_{2}$ treatment registered more GDD to attain physiological maturity than that of $\mathrm{N}_{0}$ and $\mathrm{N}_{1}$ treatment. $\mathrm{N}_{2}$ treatment has prolonged the growth period which lead to more plant growth and crop acquired more GDD over the lower level of $\mathrm{N}$ fertilization. This indicates that improvement in fertility level through $\mathrm{N}$ fertilizer help attain crop growth stages earlier by decreasing the degree days requirement of the crop due $\mathrm{N}$ application, which enhances the vegetative growth. The reduction in accumulated GDD to attain maturity during the year 2013 was mainly attributed to reduction in growing period as a result of subsoil compaction and increase in minimum temperature over the year 2012 .

The inference drawn indicates that crop growth is not only dependent on prevailing atmospheric temperature but also on essential plant nutrients. According to Liebig's law of minimum the crop growth is limited by the growth factors which are available in minimum. The atmospheric temperature during the crop season remained within the optimum range, therefore, the plant growth was directly proportional to subsoil compaction and $\mathrm{N}$ fertilization.

The subsoil compaction and $\mathrm{N}$ fertilization treatments had higher PTI at the early stages and gradually decreased towards the maturity stage (Table 4). Higher PTI was recorded for treatment $\mathrm{C}_{2}$ and $\mathrm{N}_{0}$ level. The decrease in PTI at later stage was due to the increasing growth duration at the 
Table 5. Effect of subsoil compaction and nitrogen fertilization on grain yield and heat use efficiency of maize

\begin{tabular}{|c|c|c|c|c|}
\hline \multirow{2}{*}{ Treatment } & \multicolumn{2}{|c|}{ Grain yield $\left(\mathrm{t} \mathrm{ha}^{-1}\right)$} & \multicolumn{2}{|c|}{ Heat use efficiency $\left(\mathrm{Kg} \mathrm{ha}^{-1}{ }^{\circ} \mathrm{C}\right.$ days $\left.^{-1}\right)$} \\
\hline & 2012 & 2013 & 2012 & 2013 \\
\hline \multicolumn{5}{|c|}{ Subsoil compaction levels } \\
\hline $\mathrm{CO}$ & 6.307 & 5.494 & 3.21 & 2.92 \\
\hline $\mathrm{C} 1$ & 5.738 & 4.391 & 2.99 & 2.40 \\
\hline $\mathrm{C} 2$ & 5.326 & 4.158 & 2.72 & 2.31 \\
\hline $\mathrm{LSD}-\mathrm{C}$ & 0.67 & 0.87 & 0.35 & 0.46 \\
\hline \multicolumn{5}{|c|}{ Nitrogen levels } \\
\hline N0 & 5.400 & 4.346 & 2.75 & 2.38 \\
\hline N1 & 5.763 & 4.646 & 3.00 & 2.53 \\
\hline N2 & 6.209 & 5.049 & 3.17 & 2.72 \\
\hline LSD- N & 0.47 & 0.52 & 0.22 & 0.25 \\
\hline $\operatorname{LSD} \mathrm{C} \times \mathrm{N}(\mathrm{P}=0.05)$ & ns & ns & ns & ns \\
\hline
\end{tabular}

advanced phenological stages of the maize. It was observed that the PTI gradually increased with increase in fertility level through $\mathrm{N}$ fertilizer for attaining silk and physiological maturity stage. However, for attaining tasseling stage, a reverse trend was observed i.e. decreased from lower fertility level to higher fertility level. Increasing level of $\mathrm{N}$ fertilizer lowered the PTI requirement because degree days consumed as well as number of days between two stages decreased and crop reached different stages earlier than the crop with non compacted subsoil and recommended N. Thus, it resulted in highest PTI requirement. The trend was uniform during both the years and for all growth stages.

Effect of subsoil compaction and $\mathbf{N}$ fertilization on maize yield: Subsoil compaction and $\mathrm{N}$ fertilization significantly affected the grain yield of maize during both years of the study (Table 5). Experimental plot without subsoil compaction $\left(\mathrm{C}_{0}\right)$ recorded highest grain yield during both years of study. Higher level of subsoil compaction resulted in yield reduction that varied from 15 to $25 \%$. Gaultney et al. (1980) also reported 45-50 per cent yield reduction in maize due to subsoil compaction. Highest grain yield was achieved under non compacted subsoil $\left(\mathrm{C}_{0}\right)$ treatment than that in $\mathrm{C}_{1}$ and $\mathrm{C}_{2}$ treatments during year 2012 and 2013. The maize yield reductions under higher degree of subsoil compaction occurred due to root growth restrictions. Allmaras et al. (1988) also found lower yield as a result of root growth restrictions under subsoil compaction. In addition to this crop took less number of days to mature under higher degree of subsoil compaction and ultimately it had reduced crop yield. Muchow, (1990) had also observed reduced grain yield due to shorter grain filling period resulting from early maturity. $\mathrm{N}$ application significantly affects the grain yield (Table 5). The increase in $\mathrm{N}$ dose from $155 \mathrm{Kg} \mathrm{N}^{-1}$ to $235 \mathrm{Kg} \mathrm{N}$ $\mathrm{ha}^{-1}$ resulted in 14.8 and 16.1 per cent increase in grain yield during the year 2012 and 2013, respectively. An increase in grain yield is attributed to higher plant growth in response to higher level of $\mathrm{N}$ fertilization over the recommended dose of $\mathrm{N}$. Our finding confirms the finding of Inamullah et al. (2011) who found increased grain yield with higher dose of nitrogen.

Effect of subsoil compaction and $\mathbf{N}$ fertilization on heat use efficiency: The higher levels of subsoil compaction adversely affect the HUE of maize and resulting from lower grain yield (Table 5). However, $\mathrm{N}$ fertilization had favorable effects on HUE due to higher grain yield and prolonged growth period. An improvement in the HUE was observed with the increase in fertility level and advancement of the crop stage as a result of $\mathrm{N}$ fertilization that enhanced the ability of the plant to utilize thermal heat for its development. This reduced HUE under higher level subsoil compaction was due to shortened growth period, lesser AGDD and reduced yield.

\section{Conclusion}

The present investigation concludes that the soil compaction adversely affect the phenology of crop resulting in yield reduction and reduced heat use efficiency. The $\mathrm{C}_{2}$ subsoil compaction treatment had significantly delayed the occurrence of tasseling and silking stage, while, advanced the physiological maturity. Nitrogen application above the recommended dose had advanced the occurrence of tasseling and silking stage, while delayed the physiological maturity of crop, and improved crop yield and HUE. The crop acquired lesser AGDD under $\mathrm{C}_{2}$ treatment than that in $\mathrm{C}_{0}$ treatment leading to lower HUE. The various thermal indices used to predict crop yield are based on the canopy temperature, which could lead to serious error, if the soil strength and soil nutrition parameters are not considered. The present study revealed the need to take care of soil strength, soil temperature and soil nutrition related parameters for better yield prediction of maize using various thermal indices. 


\section{ACKNOWLEDGEMENT}

We thank the Department of Soil Science, Punjab Agricultural University, Ludhiana for providing field and lab facilities to conduct this experiment. We also appreciate Kuldeep Singh for his assistance with sample collection, laboratory analysis and crop management. We thank the anonymous reviewers for their critical comments and suggestions for the improvement of manuscript.

\section{REFERENCES}

Abu-Hamdeh, N.H. (2003). Compaction and subsoiling effects on corn growth and soil bulk density. Soil Science Society America Journal, 67: 1213-19.

Abayomi, Y. A. and Adedoyin, G. A. (2004). Effect of planting date and fertilizer application growth and yield of contrasting maize (Zea mays L.) Genotypes II: Morphophysiological growth characters and their contribution to grain yield. Nigerian Journal Pure \& Applied Science, 19: 1641-1652.

Ali, K., Munsif, F., Din, I. U., Khan, A. and Khan N. (2012). Maize phenology as affected by tillage practices and nitrogen sources. Agricultural Sciences Research Journal, 2:453-458.

Allmaras, R.R. Kraft, J.M. and Miller, D.E. (1988). Effects of soil compaction and incorporated crop residue on root health. Annal Review Phytopath ology, 26: $219-43$.

Anonymous (2012) Package of practices for crops of Punjab: Kharif 2012. Punjab Agricultural University, Ludhiana. 29(1): 18-30.

Dawadi, D.R. and Sah, S.K. (2012). Growth and yield of hybrid maize (Zea mays L.) in relation to planting density and nitrogen levels during winter season in Nepal. Tropical Agricultural Research, 23: 218-27.

Domzal, H., Glinski, J. and Lipiec, I. (1991). Soil compaction research in Poland. In: Van Ouwerkerk, C. (Ed.), Soil Compaction and Plant Productivity, Elsevier, Amsterdam, the Netherlands, pp. 99-109.

Ellis, R.H., Hadley, P., Roberts, E.H. and Summerfield, R.J. (1990). Relations between temperature and crop development. In Jackson, M. Ford-Lloyd, B. V. and Parry, M. L. (Eds) Climate change and plant genetic resources, Belhaven Press, London, pp 85-115.

Flowers, M. and Lal, R. (1998). Axle load and tillage effect on soil physical properties and soybean grain yield on a Mollic Ochraqualf in Northwest Ohio. Soil and Tillage Research, 48: 21-35.

Gajri, P.R., Arora, V.K. and Chaudhary, M.R. (1994). Maize growth responses to deep tillage straw mulching and farmyard manure in a coarse textured soils of NW India. Soil Use Management, 10: 15-20.

Gaultney, L., Krutz, G.W., Steinhardt, G.C. and Liljedahl (1980). Field and laboratory tests to determine effects of subsoil compaction on corn yield. ASAE paper no 801011. ASAE St. Joseph, MI. USA.

Gomez, K. A. and Gomez, A. A. (1984). Statistical Procedures for Agricultural Research, John Wiley and Sons, Inc, U K.

Habtegebrial, K., Singh, B.R. and Haile, M. (2007). Impact of tillage and nitrogen fertilization on yield, nitrogen use efficiency of Eragrostis, Trotter and soil properties. Soil and Tillage Research, 94: 55- 63.

Hanway, J.J. (1963). Growth stages of corn (Zea mays L.). Agronomy Journal, 55: 487-92.

Iijima, M., Kono, Y., Yamauchi, A. and Pardales Jr, J. R. (1991). Effects of soil compaction on the development of rice and maize root system. Environment Experimental Botany, 30: 333-42.

Inamullah, Shah, N.H., Rehman, N., Siddiq, M. and Khan, Z. (2011). Phenology, yields and their correlations in popular local and exotic maize hybrids at various nitrogen levels. Sarhad Journal Agriculture, 27: 36369.

Kumar, R., Ramesh, K., Singh, R.D. and Prasad, R. (2010). Modulation of wild marigold (Tagetes minuta L.) phenophases towards the varying temperature regimes - a field study. Journal Agrometeorology, 12: $234-40$.

Motavalli, P.P., Anderson, S.H. and Pengthamkeerati, P. (2003). Surface compaction and poultry litter effects on corn growth, nitrogen availability, and physical properties of a claypan soil. Field Crop Research, 84: 303-18.

Muchow, R.C. (1990). Effect of high temperature on grain -growth in field-grown maize. Field Crop Research, 23:145-58.

Nuttonson, M.Y. (1955). Wheat climatic relationship and use of phenology in ascertaining the thermal and photo thermal units of wheat. Am. Inst. Crop Ecol. Washington D.C.

Ogola, J.B.O., Wheeler, T.R. and Harris, P.M. (2002). Effects of nitrogen and irrigation on water use of maize crops. Field Crop Research, 78:105-17.

Shafi, M., Bakht, Jan M. T., and Shah Z. (2007). Soil C and $\mathrm{N}$ dynamics and maize yield as affected by cropping systems and residue management in Northwestern Pakistan. Soil and Tillage Research, 94: 520-29.

Stone, P.J. Sorensen I.B. and Jamieson P.D. (1999). Effect of soil temperature on phenology, canopy development, biomass and yield of maize in a cooltemperate climate. Field Crop Research, 63: 169-78.

Streck, N.A., Lago, I., Gabriel, L.F. and Samboranha, F.K. (2008). Simulating maize phenology as a function of air temperature with a linear and a nonlinear model. Pesquisa Agropecuária Brasileira, 43: 449-55.

Sur, H.S., Prihar, S.S. and Jalota, S.K. (1980). Effect of rice-wheat and maize-wheat rotation on water transmission and wheat root development in a sandy loam soil of Punjab, India. Soil and Tillage Research, 1: 361-71.

Uhart, S.A. and Andrade, F.H. (1995). Nitrogen deficiency in maize. I. Effects on crop growth, development, dry matter partitioning, and kernel set. Crop Science 35:1376-83.

Uribelarrea, M., Crafts-Brandner, S.J. and Below F.E. (2009). Physiological $\mathrm{N}$ response of field-grown maize hybrids (Zea mays L.) with divergent yield potential and grain protein concentration. Plant and Soil, 316: 151-60. 